\title{
Table Grapes during Postharvest Storage: A Review of the Mechanisms Implicated in the Beneficial Effects of Treatments Applied for Quality Retention
}

\author{
Irene Romero, Maria Vazquez-Hernandez, Isaac Maestro-Gaitan, Maria Isabel Escribano, \\ Carmen Merodio and Maria Teresa Sanchez-Ballesta *(D) \\ Department of Characterization, Quality and Safety, Institute of Food Science, Technology and \\ Nutrition (ICTAN-CSIC), Ciudad Universitaria, E-28040 Madrid, Spain; irene.romero@ictan.csic.es (I.R.); \\ mavahe86@gmail.com (M.V.-H.); isaac.maestrogaitan@gmail.com (I.M.-G.); escribano@ictan.csic.es (M.I.E.); \\ merodio@ictan.csic.es (C.M.) \\ * Correspondence: mballesta@ictan.csic.es
}

Received: 13 November 2020; Accepted: 6 December 2020; Published: 7 December 2020

\begin{abstract}
Table grape is a fruit with increasing interest due to its attributes and nutritional compounds. During recent years, new cultivars such as those without seeds and with new flavors have reached countries around the world. For this reason, postharvest treatments that retain fruit quality need to be improved. However, little is known to date about the biochemical and molecular mechanisms related with observed quality improvements. This review aims to examine existing literature on the different mechanisms. Special attention will be placed on molecular mechanisms which activate and regulate the different postharvest treatments applied in order to improve table grape quality.
\end{abstract}

Keywords: table grapes; fruit quality; postharvest; physical treatments; mechanisms; gene expression

\section{Introduction}

Table grape cultivars (Vitis vinifera L. and V. vinifera hybrids with $V$. labrusca L. and V.amurensis Rupr.) are from the Vitaceae family of deciduous woody perennial plants, being one of the most consumed non-climacteric fruits worldwide. Table grape is a fruit with a relatively low rate of physiological activity which does not ripen further after harvest. Its quality refers to different attributes related to appearance, color, texture, flavor and aroma. Its evolution begins as the "veraison" stage with the onset of ripening, alongside the accumulation of sugars, berry softening, anthocyanin synthesis, the metabolism of organic acids and the accumulation of flavor compounds [1]. Soluble solid content $\left({ }^{\circ}\right.$ Brix) and sugar/acid ratios serve as primary indices of table grape quality and minimum requirements have been specified for each cultivar. Table grape flavor is a complex and important quality since it is a mixture of hundreds of different volatile compounds which are synthesized during ripening. After harvest, table grapes are highly perishable as they are subjected to important water losses as a result of rachis and pedicel desiccation, causing browning, weight loss and berry softening. Moreover, fungal decay, largely caused by the necrotrophic pathogen Botrytis cinerea also produces big losses [2]. This fungus has a high growth rate and a strong ability to spread through berries even at low temperatures around $0{ }^{\circ} \mathrm{C}$. As a result of this, its conservation is limited and depends on numerous internal factors such as the structure and consistency of the skin and pulp, and the maturation ratio, as well as external factors, with temperature and relative humidity being the most important.

Consumers' high acceptance of table grapes is due to their excellent organoleptic and nutritional qualities, and has led to significant growth in their consumption over recent years. According to 2019 data from the International Organization of Vine and Wine (OIV), approximately $36 \%$ of total grape production was destined for fresh consumption, with China being the largest consumer, followed by 
India and the European Union (EU). Table grape production has doubled in the last twenty years. According to USDA data, world production for 2019/20 is projected to be around 23.4 million tons. Although the impact of COVID-19 has been considered within this global forecast of trade of table grapes, the exact impact of the pandemic is still unclear since its duration and effects on the global economy are still uncertain. China is the major producer ( 9.5 million tons), followed by Turkey and India who both produce 1.9 million tons (data from OIV for 2018). In reference to world exports, Chile, Italy, and the USA are the three largest exporters of table grapes and, together, these three countries account for $40 \%$ of the total. Likewise, many developing countries have substantially increased their table grape exports as it is a source of economic growth. This fact, together with increasing societal awareness about the environment and sustainable development, has promoted research in postharvest technologies to uncover ways of reducing the use of agrochemical compounds, whilst still maintaining the quality of fruit during its storage.

Although in recent years different reviews have described technological advances in maintaining the quality of table grapes during postharvest [2-5], the mechanisms through which they exert their beneficial effects require an in-depth review. Thus, the present work aims to review existing literature on the different potential mechanisms, giving special attention to molecular mechanisms regulated by the postharvest treatments applied in order to improve table grape quality. Although we have made an effort to review the mechanisms behind different postharvest treatments, it is important to highlight that most published studies up until now examining both the effectiveness of treatments and their mechanisms, have used the modification of storage atmosphere composition as the only postharvest treatment.

\section{Mechanisms Associated with Effectiveness of the Postharvest Treatments Applied to Maintain Table Grape Quality}

\subsection{Effect on the Cell Wall}

Dynamic changes in the chemical composition of the cell wall, as well as in the tissue structure during fruit ripening, senescence and postharvest storage may cause variations in the sensory, chemical and physical properties of table grapes. Plant cell walls are complex, interconnected structures of polysaccharides (pectin, cellulose and hemicellulose), cell wall proteins and polyphenols [6]. The cell wall of grape berries acts as a protection against external factors and forms a barrier to prevent the diffusion of different components including aromas and polyphenols compounds [7].

Firmness of table grapes is an essential quality parameter for consumers and excessive softening may lead to postharvest decay or consumer rejection. Fruit softening occurs primarily through modifications to the cell wall as the result of cell wall polymer degradation which is catalyzed by diverse enzymes such as cellulase (CL), polygalacturonase (PG), $\beta$-galactosidase ( $\beta$-GAL), pectate lyase (PL) and xyloglucan endotransglycosylase/hydrolase (XTH) $[8,9]$. Changes to the cell wall composition and degrading enzyme activity have been reported during grape ripening [10,11]. Moreover, previous studies indicated that berry firmness during ripening involves complex multigene control [12,13]. Thus, Ma et al. [14] reported that the firmness of Red Globe grapes was significantly higher than that of Muscat Hamburg fruit during ripening, with this seemingly related to the differential expression of the pectinesterase (PE),PL, PG, $\beta$-GAL, galacturonosyltransferase-like, wall-associated receptor kinase-like, $\mathrm{XTH}$ and expansins. However, the process of berry softening during postharvest is not completely understood and most existing works are focused on changes in enzymatic activities and microstructure, so little is known at a molecular level. Thompson seedless grapes with significantly decreased berry texture following prolonged cold storage have been compared with NN107 fruit, which is a new table grape cultivar with higher berry firmness. This comparison showed differences in cell wall metabolism between both cultivars [15]. Thus, the high calcium content, low uronic acid degradation and reduced PG activity observed in NN107 bunches seem to be associated with its firmer grape berry texture phenotype and higher quality during prolonged cold storage. Moreover, the application of high $\mathrm{O}_{2}$ levels in Kyoho grapes (V. vinifera L. $\times$ V. labrusca L.) retarded grape berry softening and reduced levels 
of PG, PE and $\beta-G A L$, and CL activities [16]. At a molecular level, it is known that the application of $30 \mathrm{kPa}$ of $\mathrm{CO}_{2}$ for 3 days at $20{ }^{\circ} \mathrm{C}$ in detached white wine grapes, down-regulates the expression of genes coding for pectin methylesterase and polygalacturonase. These are two pectin-degrading enzymes which are responsible for softening [17]. Moreover, in other fruits such as strawberries, exposure to $30 \% \mathrm{CO}_{2}$ for $3 \mathrm{~h}$ at $25^{\circ} \mathrm{C}$ delayed cell wall degradation, maintaining the integrity of the middle lamella and down-regulating genes related to cell wall degradation enzymes [18]. Short-term high $\mathrm{CO}_{2}$ treatments have been described as alleviating flesh gelling during the storage of persimmon at low temperature. This occurs by preserving the integrity of cell walls and the plasmalemma [19]. Low temperature-scanning electron microscopy has been used in $\mathrm{CO}_{2}$-treated and non-treated table grapes to examine the microstructure of the epidermal and subsequent hypodermal cells of the skin. The most notable outcome being that grapes stored in air showed greater cellular compression and volume loss [20]. Moreover, cell wall-plasma membrane separation was detected in cells of non-treated Autumn Royal grapes after 41 days at $0{ }^{\circ} \mathrm{C}$. However, double application of a short-term high $\mathrm{CO}_{2}$ treatment improved table grape quality and maintained the membrane completely fixed to the cell wall until the end of the cold storage period [21].

\subsection{Effect on the Plasma Membrane}

To date, the mechanisms by which plants sense low temperature are not yet fully understood. Multiple primary sensors are thought to be involved in initial cold stress signaling. Each sensor may perceive a specific aspect of cold stress and may be involved in a distinct branch of the signaling pathway [22]. Plants may sense low temperature through changes in membrane fluidity, permeability properties and fatty acid composition due to an increase in the content of polyunsaturated lipids [23,24].

Due to the importance of maintaining cell membrane integrity during postharvest storage of table grapes at low temperature, the effect of different treatments has been analyzed. The conservation of table grapes in controlled atmospheres with high levels of $\mathrm{O}_{2}$ improved the quality of the berries, maintaining the membranes by delaying the increase in ion leakage. This is an indicator of reduced membrane integrity that takes place in fruit stored in air [25]. The application of high levels of $\mathrm{CO}_{2}$ significantly reduced ion leakage in Cardinal table grapes stored at $0{ }^{\circ} \mathrm{C}$ in comparison to non-treated grapes [26]. A similar effect was reported after exogenous treatment of polyamines in table grapes, presumably due to maintaining membrane integrity via the accumulation of unsaturated fatty acids [27]. Likewise, the application of short-term high $\mathrm{CO}_{2}$ treatments in Autumn Royal table grapes maintained the integrity of the microstructure of energy-related cell organelles which are essential for metabolic damage repair and cell membrane restoration. Moreover, a gaseous treatment increased the unsaturation of 18-carbon fatty acids, lipid unsaturation ratio and unsaturated fatty acid index in the membrane of polar lipids [21]. Furthermore, it has been suggested that the application of a 2-day $\mathrm{CO}_{2}$ treatment in strawberries adjusts fruit metabolism, resulting in $\alpha$-linolenic acid accumulation which could confer membrane stability during low temperature storage [28].

In consideration of the important role of the membrane and its lipid composition for maintaining fruit quality during postharvest storage, researchers have endeavored to reveal the molecular mechanisms underlying lipid metabolism [29]. However, little information is available in table grapes during postharvest. Phospholipase D, a key enzyme in membrane lipid metabolism, experienced significantly increased enzyme activation, mRNA accumulation and synthesis of new protein during the early stages of heat acclimation. This suggests that phospholipase D may be involved in the heat response of grapes during postharvest [30]. Temperature-induced lipocalin (TIL) is involved in the transport of sterol molecules to the plasma membrane in response to stress conditions, with this increasing membrane fluidity at low temperature [31]. Induction of TIL gene expression in citrus fruit stored at low temperature has also been reported. This observation hints at the participation of these genes in promoting tolerance of cold stress [32]. A comparative large-scale transcriptional analysis has been conducted of the response of table grapes to low temperature and high $\mathrm{CO}_{2}$ levels. This revealed that the induction of TIL and LTP gene expression in response to cold storage could be 
related to the mechanisms activated in non-treated grapes to overcome low temperature storage [26]. LTPs belong to the most functionally important classes of plant proteins as they not only bind lipids, but have also been seen to transfer them between membranes in in vitro experiments [33]. Moreover, LTP stabilization of membranes under stress has been explicitly demonstrated, particularly in the case of cold stress [34].

Another important factor in the study of biomembranes is the specific effect that water exerts on them. Although grapes present a low respiratory rate after harvest and the layer of cuticular wax controls water movement between the epidermal cells and the ambient atmosphere [35], small modifications in the content or state of water can be responsible for very significant changes in the metabolism of grape bunches [36,37]. Likewise, the loss of water equivalent to about $5-10 \%$ of fruit fresh weight can render the fruit commercially unacceptable [38]. On the other hand, rachis lacks the thick epidermis and cuticular wax depositions that protect berries against dehydration. Thus, water losses of $2 \%$ to $3 \%$ are sufficient to make rachis show symptoms of browning [39]. This affects markets in which the condition of rachis grapes, in terms of color and turgor, is a good indicator of postharvest quality. In this sense, it has been observed that storage at $0-1{ }^{\circ} \mathrm{C}$ and a relative humidity of $95 \%$ is not enough to control water loss from bunches, with this being linked to an increase in rachis browning [40-42]. However, postharvest treatments based on altering the composition of storage atmospheres such as MAP, CA and 3-day short-term high $\mathrm{CO}_{2}$ treatment reduced water loss and controlled rachis browning during storage $[41,43,44]$.

The degree of water availability determines the properties of membrane lipids and, therefore, can affect the biophysical properties of membranes. Cold storage processes in tulip bulbs were accompanied by conversion of bound water to free water [45]. In line with these results, unfreezable water levels in the different tissues (skin, pulp, seeds and rachis) of Cardinal table grapes measured by differential scanning calorimeter, increased rapidly in response to high $\mathrm{CO}_{2}$. In contrast, these water levels remained stable or decreased in grapes stored in the air [36]. Moreover, cold acclimation of vegetative apple buds seems to involve several processes including an increase in the levels of unfreezable water [46]. Furthermore, Blanch et al. [37] indicated that storage of strawberries in air at $0{ }^{\circ} \mathrm{C}$ led to a marked decrease in the unfreezable water proportion, an increase in cellular water leakage, cell structure disorganization and water potential. On the other hand, a 3-day $\mathrm{CO}_{2}$ treatment led to the maintenance of a similar water status as that found in freshly harvested fruit. Unfreezable water content is associated with membranes, proteins and macromolecules [47]. Goñi et al. [36] indicated that increases in unfreezable water content may, therefore, constitute a sensory parameter that reflects metabolic adaptations in $\mathrm{CO}_{2}$-treated tissues due to the alterations caused by storage in air at severely low temperature.

\subsection{Effect on Oxidative Stress}

Apart from the direct effect of low temperature storage on the molecular organization of membrane lipids, the loss of integrity of the membrane itself is boosted by oxidative processes. This is because low-temperature stress increases levels of reactive oxygen species (ROS) (reviewed in [48]). When plants are subjected to environmental stress such as low temperature, the balance between ROS production and detoxification is upset, often resulting in oxidative damage. Plants are protected against the effects of ROS by their complex antioxidant system. This includes antioxidant metabolites such as ascorbate, glutathione, $\alpha$-tocopherol and $\beta$-carotene, alongside antioxidant enzymes such as superoxide dismutase (SOD), catalase (CAT), ascorbate peroxidase (APX) and glutathione reductase (GR) [49-51]. In contrast to earlier views, it is becoming increasingly evident that even during stress, ROS production is not necessarily a symptom of cellular dysfunction but might represent a necessary signal in adjusting the cellular machinery to the altered conditions (reviewed in [51]). ROS, especially $\mathrm{H}_{2} \mathrm{O}_{2}$, are proposed to perform multiple functions such as acting as a signal transducer in plant defense against both biotic and abiotic stresses, including low temperature (reviewed in [52]). 
It is known that fruit modulate their antioxidant defenses during storage at low temperature or in response to different postharvest treatments. Pavez et al. [53] reported that peach fruit were able to respond to the increased production of ROS induced by extended cold storage. This occurred through the induction of genes encoding $\mathrm{CAT}$, SOD and GR. Moreover, high $\mathrm{CO}_{2}$ levels can mitigate the impact of heat on different coffee species (Coffea arabica and Coffea canephora) by increasing the antioxidant activity of enzymes such as SOD, APX, GR and CAT [54]. In strawberries, there is a marked increase in GR activity associated with the NADPH produced by active malic acid decarboxylation. This may account for the increased levels of glutathione seen in fruit following exposure to $20 \%$ $\mathrm{CO}_{2}$ [55] Moreover, Yuan et al. [56] observed the induction of different antioxidant enzymes including APX, glutathione S-transferase and oxidoreductase during the storage of Kyoho grapes at $2{ }^{\circ} \mathrm{C}$. In a recent study, it was reported that accumulation of CAT and APX transcripts in the skin of non-treated grapes from black (Autumn Royal) and white (Superior Seedless) cultivars seems to be activated. This may take place in order to overcome oxidative stress due to cold storage, with this being less noticeable in $\mathrm{CO}_{2}$-treated samples [44]. Conversely, $\mathrm{Ni}$ et al. [57] reported that gaseous treatment with hydrogen sulfide alleviated postharvest senescence and rotting in Kyoho grapes. This occurred by enhancing the activity of APX and CAT in both grape skin and pulp during storage. A transcriptome analysis showed that the molecular signature of $\mathrm{SO}_{2}$ application was highly similar to superoxide stress, evoking a broad metabolic reprogramming in table grape berries. This was consistent with an up-regulation of tolerance and mechanisms, and the associated ROS/redox [58]. However, the beneficial effect of high $\mathrm{CO}_{2}$ levels on controlling oxidative stress by modulating the genes implicated in the enzymatic antioxidant system, depended on tissue type and was closely related with browning reductions in rachis grapes, specifically, rather than with a general response in table grapes [26,44].

It is known that when ROS levels exceed the capacity of plants to scavenge, lipid peroxidation in biological membranes increases, thereby affecting the physiological processes of the cell. Malondialdehyde (MDA) is one of the final products of the oxidative modification of lipids. Its content reflects the state and integrity of plant cell membranes and has been extensively used as an indicator of oxidative injury. In this respect, MDA production is clearly implicated in the symptoms of environmentally stressed plants [59]. It is known that the application of postharvest treatments enhances chilling tolerance in fruit and reduce MDA content [60-62]. In table grapes, different studies have indicated that storage atmosphere modifications control the MDA content increases activated during cold storage. In this way, 3-day $\mathrm{CO}_{2}$ treatments applied either once or twice have delayed postharvest cold-increase in $\mathrm{H}_{2} \mathrm{O}_{2}$ and MDA content in Autumn Royal berries [21]. Moreover, the reduction in rachis browning and MDA content observed in 3-day $\mathrm{CO}_{2}$-treated Cardinal bunches was linked to activation of the enzymatic antioxidant system. This was also associated with significant increases in APX and CAT gene expression in this tissue [41]. Furthermore, postharvest application of nitric oxide gas at low temperature maintained the quality of Munage table grapes reducing the accumulation of $\mathrm{O}_{2}{ }^{\bullet}, \mathrm{H}_{2} \mathrm{O}_{2}$ and MDA content via the activation of ROS-related genes and antioxidant enzymes [63].

\subsection{Effect on Phenylpropanoid Metabolism}

Phenolic compounds are a group of important secondary plant metabolites which are associated with fruit quality, thus affecting appearance, taste and flavor. Specifically, grapes constitute one of the major sources of phenolic compounds amongst different fruit species [64]. These compounds have received increasing scientific interest due to their antioxidant properties and potential beneficial health effects. Thus, since the postharvest storage of table grapes may have an important impact on the phenolic compounds and enzymes involved in their metabolism, the examination of their biosynthesis and regulation is of special interest. Different studies have indicated that there is no common trend regarding total phenolic content changes, in response to postharvest treatments that improve table grape quality. The total phenolic content of red and white table grapes was found to decrease and stay the same, respectively, following 2 days of storage at $4{ }^{\circ} \mathrm{C}$, increasing thereafter in both cultivars [65]. 
Postharvest chitosan coating treatments decreased total phenol content during storage at $0^{\circ} \mathrm{C}$ and also during shelf-life [66]. However, the application of UV-B and UV-C significantly increased the content of total phenolic compounds during table grape storage at $4{ }^{\circ} \mathrm{C}$ [67]. Artés-Hernández et al. [68] reported that white Superior Seedless table grapes stored for 7 days at $0{ }^{\circ} \mathrm{C}$, followed by 4 days at $8{ }^{\circ} \mathrm{C}$ under modified atmosphere packaging, did not change their total phenolic content. Further slight decreases were seen during their subsequent shelf-life. In contrast, in the same cultivar of Superior Seedless grapes, application of a 3-day $\mathrm{CO}_{2}$ treatment at $0{ }^{\circ} \mathrm{C}$ increased phenolic content [44]. However, it is important to note that varietal factors and the stage of ripeness could determine the concentration, distribution and accumulation of polyphenols in grapes [68-70]. Further, total phenolic content decreased after 3 days of storage at $0{ }^{\circ} \mathrm{C}$ in black table grapes but did not vary in white ones [44].

The oxidative degradation of phenolic compounds catalyzed by polyphenol oxidase (PPO) and peroxidase (POD) enzymes is one of the most important issue to the food industry as it results in the enzymatic browning of fruit and vegetables [71]. It has been proposed that PPO, normally found in the chloroplast, comes into contact with the substrate in the vacuole due to the loss of compartmentalization caused by desiccation [72]. The development of rachis browning during the postharvest storage of table grapes has been associated with PPO activity [73]. Rosales et al. [41] observed that the application of a 3-day $\mathrm{CO}_{2}$ treatment at $0{ }^{\circ} \mathrm{C}$ reduced the rachis browning index and sharply increased PPO gene expression in non-treated bunches. In this sense, the application of hexanal formulation to improve table grape quality suppressed PPO-related browning which maintained rachis freshness [74].

Phenylalanine ammonia lyase (PAL) catalyzes the first reaction in the phenylpropanoid pathway, producing a wide variety of phenolic compounds which include flavonoids, phytoalexins and phenolic esters $[75,76]$. The activation of phenylpropanoid metabolism may play a role in plant defense against pathogens, as well as in the response to abiotic stresses [77,78]. Furthermore, modification of the phenylpropanoid biosynthesis pathway becomes is eased by the induction of mutations or genetic engineering, resulting in a shift in physical as well as metabolic functioning of the pathway [78]. Of the polyphenol compounds derived from the phenylpropanoid pathway, stilbenes represent defense biomarkers, because they occur as phytoalexins whose production is induced dynamically in response to biotic or abiotic stress. Stilbene synthase (STS) catalyzes, in a single reaction, the formation of simple monomeric stilbenes (e.g., resveratrol, pinosylvin and piceatannol) from coenzyme A-esters of cinnamic acid derivatives and three malonyl-CoA units [79]. The remaining stilbenes are formed as a result of glycosylation (piceids) and hydroxylation (piceatannol and its glycoside, astringin) reactions, and the formation of dimers and trimers (viniferins).

Vanozzi et al. [80] characterized the STS multigenic family from $V$. vinifera into 48 different members. STS genes have been transformed into different plants in order to improve resistance against fungal pathogens and other abiotic stresses [81-83], whilst also increasing either resveratrol accumulation [81,84] or piceid accumulation [85]. Moreover, resveratrol content increased in table grapes in response to the application of different postharvest treatments such as UV-B and UV-C irradiation [86], the combination of UV-C and chitosan coatings [87] and ozone treatment [88]. In relation to the transcriptional regulation of STS genes in table grapes, induced expression linked to increases in the accumulation of resveratrol has been reported following the application of red and blue light-emitting diodes [89] and ultrasonication [90]. Moreover, Maoz et al. [91] analyzed the expression of six STS genes in white Superior Seedless grapes treated for 6 weeks with $15 \% \mathrm{CO}_{2}$ and $5 \% \mathrm{O}_{2}$ at low temperatures. They observed increased induction at both low temperature or high $\mathrm{CO}_{2}$ levels, together with the accumulation of six viniferins and an unidentified resveratrol dimer. A recent study reported that STSs gene expression and the accumulation of stilbene compounds following the application of short-term $\mathrm{CO}_{2}$ treatment at low temperature was cultivar dependent [92]. These authors reported that a 3-day high $\mathrm{CO}_{2}$ treatment activated the expression of four STSs, whilst also activating stilbenes in the white Dominga cultivar. However, accumulation of these compounds increased in non-treated Red Globe grapes at $0{ }^{\circ} \mathrm{C}$, with this also seeming to be activated by STS expression. Moreover, prolonged 
storage at $0{ }^{\circ} \mathrm{C}$ of non-treated samples of Cardinal grapes, another red cultivar, led to increased trans-resveratrol levels but only at the end of storage [40].

Flavonoids are sensitive to different biotic and abiotic stress as part of the plant adaptation mechanisms to the environment [93]. Furthermore, it is known that the quantitative and qualitative composition of flavonoids depends on the table grape cultivar, whilst the influence of postharvest storage on their contents does not follow a regular pattern [91,94-96]. With regards to transcriptional regulation, little is known about whether the expression of branch-specific flavonoid genes is regulated by different postharvest treatments in table grapes. This is because most published works have been restricted to a small number of genes, most of which belong to the common pathway $[97,98]$. UV-B and UV-C treatments activated the expression of genes specific to flavanol formation, such as ANR (anthocyanidin reductase) and LAR (leucoanthocyanidin reductase), in Summer Black table grapes [67]. Likewise, the application of melatonin to Kyoho grapes combined with storage at $22{ }^{\circ} \mathrm{C}$ for 3 days significantly enhanced the biosynthesis of flavanol components, whilst also increasing expression of flavanol synthase (FLS) and flavonoid 3',5'-methyltransferase (AOMT). In contrast, chalcone isomerase (CHI), flavanone 3-hydroxylase (F3H), dihydroflavonol 4-reductase (DFR), leucoanthocyanin dioxygenase (LDOX) and ANR accumulation was inhibited [99]. Likewise, $P A L$ and $L A R 2$ expression seems to be a regulating factor of catechin accumulation in $\mathrm{CO}_{2}$ table grapes [96]. Moreover, the grape genotype seems to be an important factor to be considered for the modulation of common flavonoid genes, following short-term $\mathrm{CO}_{2}$ treatments applied at low temperature $[96,97]$. However, $\mathrm{SO}_{2}$ application for 21 days strongly down-regulated $L A R$ and ANR transcript accumulation [14].

With regards to anthocyanins, it is known that low temperature postharvest storage activates modulation in different fruits including table grapes. Furthermore, various studies have shown that treating harvested fruit with high levels of $\mathrm{CO}_{2}$, for instance by controlling the atmosphere or modified atmosphere packaging, inhibits the increase of anthocyanin by affecting its biosynthesis, degradation, or both (reviewed by [100]). However, whilst a decrease in the content of all identified anthocyanins has been recorded in black Autumn Royal table grapes stored at $0{ }^{\circ} \mathrm{C}$, a dual short-term $\mathrm{CO}_{2}$ treatment was seen to maintain levels after 28 days at $0^{\circ} \mathrm{C}$ similar to freshly harvested fruit, which was correlated with the expression of CHS, LDOX and UDP-glucose: flavonoid 3-O-glucosyltransferase (UFGT) genes [96]. Moreover, the application of light irradiation at $15-25^{\circ} \mathrm{C}$ as a postharvest technique for stable production of well colored grapes, also increased anthocyanin levels. This was linked with greater induction of anthocyanin biosynthesis-related genes including CHS, LDOX and UFGT, and two $M Y B$-related transcription factors [101]. Likewise, low nocturnal temperatures increased anthocyanin synthesis in black grape berries through the regulation of PAL activity and CHS gene expression [102].

\subsection{Molecular Basis of the Response of Table Grapes to Postharvest Treatments}

The sequencing of the $V$. vinifera cultivar Pinot Noir resulted in the first genome of a woody crop species [103,104]. Numerous assemblies and annotations of the PN40024 reference genome [103] have been performed, with the latest version $(12 \times v$. 2 assembly and VCost.v. 3 annotation) improving contig coverage and orientation by $14 \%$ over the previous assembly $(12 \times$ v. 0$)$ and annotation (v. 1) [105].

The generation of transcriptome data together with functional analysis of identified candidate regulatory genes, represent powerful tools for unraveling the molecular mechanisms underlying the response of table grapes to postharvest treatments. Thus, high-throughput transcriptomic analysis via microarrays has become a key tool for understanding these molecular changes. Becatti et al. [17] used the Array-Ready Oligo Set ${ }^{\mathrm{TM}}$ containing 14,562 probes to examine detached wine grapes following treatment with $30 \mathrm{kPa}$ of $\mathrm{CO}_{2}$ for 3 days at $20^{\circ} \mathrm{C}$. They found this treatment to be effective at altering general metabolism, with functional categories related to protein and hormone metabolism, transport and stress being more highly represented in both skin and pulp tissues. A transcriptome analysis using the GeneChip ${ }^{\circledR}$ V. vinifera genome array from Affymetrix and containing probe sets for approximately 16,000 genes, suggested that $\mathrm{SO}_{2}$ application has similar effects to superoxide stress. This includes the down-regulation of WRKY and $b H L H$ transcription factors, which are strongly 
up-regulated by other ROS stresses. Similarities were also seen with profiles associated with ROS, other than superoxide, including the up-regulation of ERFs transcription factors [58]. Moreover, a custom Affymetrix GrapeGen GeneChip ${ }^{\circledR}[106]$ containing 23,096 probe sets corresponding to 18,711 non-redundant transcripts was used to examine changes in the transcriptome of Cardinal table grape skin at different stages of maturity. Following exposure to high levels of $\mathrm{CO}_{2}$ and $0{ }^{\circ} \mathrm{C}$ for 3 days, it was seen that the gaseous treatment seems to be an active process requiring the activation of different transcription factors, including ethylene response factors (ERFs), WRKYS and MYBs [26].

In taking a closer look at the role of transcription factors it is important to note that most studies in $V$. vinifera have been performed on grapevine seedlings or during grape ripening [107-112] with little being known about their role postharvest. A short-term high $\mathrm{CO}_{2}$ treatment has been observed to activate the expression of transcription factors belonging to the APETALA2/ethylene response factor (AP2/ERF) family. These factors include four ERFs [113] and three CBF/DREBs [42], in addition to nine WRKYs [114] seen in red and black table grapes. These transcription factors evidenced "switch mode" expression patterns, with induction taking place at the end of gaseous treatment followed by a rapid decline. It is important to note that similar results were observed as a response of fruit to low temperature during postharvest storage $[115,116]$. This suggests that this mode of modulation is a factor in turning on transcription factors and, consequently, activating or repressing target genes. This may be critical for fruit protection from stress damage during postharvest. However, Maoz et al. [91] showed that storage of white Superior Seedless grapes for 6 weeks, either at $0{ }^{\circ} \mathrm{C}$ in air or with $15 \mathrm{kPa} \mathrm{CO}$, did not activate the expression of ERFs and CBFs in comparison to freshly harvested fruit. However, it is difficult to compare results because the gaseous treatments applied were different, with Maoz et al. [91] applying a continuous gaseous treatment for 6 weeks and Romero et al. [113] opting for a 3-day short-term treatment. Further, nine WRKYs genes were also induced in 3-day $\mathrm{CO}_{2}$-treated Autumn Royal table grapes stored at $0{ }^{\circ} \mathrm{C}$ [114].

Moreover, different studies have shown that CBF/DREB [42], ERF [113] and WRKY [114] recombinant proteins from table grapes bind in vitro to the regulatory regions of their downstream target genes, such as pathogenesis related proteins (PRs) and dehydrins. Multiple PR isoforms belonging to the chitinase and $\beta$-1,3-glucanase family have also been reported in grapes $[117,118]$, but available data concerning their expression in grape berries are limited. Increased levels of chitinase and glucanase transcripts and activity have been reported in grapevines infected with B. cinerea (reviewed in [119]). Busam et al. [117] reported that the expression of a class III chitinase gene might serve as a marker for systemic acquired resistance in grapevine leaves. Likewise, the introduction of both $\beta-1,3$-glucanase and chitinase genes into transgenic Crimson Seedless lines confers markedly improved resistance to downy mildew [120]. Furthermore, Crimson Seedless lines expressing cisgenic thaumatin-like proteins from $V$. vinifera Chardonnay have displayed resistance to powdery mildew [121].

It has been reported that PRs seem to have a protective role in table grapes postharvest. Thus, overexpression of chitinase and $\beta$-1,3-glucanase proteins from table grapes in Escherichia coli has been shown to boost in vitro cryoprotective activity and antifungal activity [116,117]. Application of $\mathrm{SO}_{2}$ or $\mathrm{O}_{3}$ caused delayed decay by $B$. cinerea in Redglobe and Sugraone grape cultivars, however, whilst gene expression of chitinase and $\beta$-1,3-glucanase was increased in treated Redglobe grapes, neither treatment enhanced expression of these PR genes in Sugraone grapes. This may partly explain why this cultivar is more susceptible to decay [122]. Likewise, Wang et al. [123] recently observed that the reduction of grey mold decay caused by B. cinerea in Kyoho grape berries treated with $\beta$-aminobutyric acid could be attributed to systemic acquired resistance (SAR) defense. This is because a significant increase in the transcript levels of $V v P R 1$ and endogenous salicylic acid content was observed following $\beta$-aminobutyric acid elicitation.

With regards to dehydrins in $V$. vinifera, it has been reported that four of five examined genes showed alternative splicing, leading to the retention of an intron and giving rise to truncated proteins [124-127]. Fernandez-Caballero et al. [125] described intron retention in VviDHN1a transcripts in response to both cold storage and a 3-day $\mathrm{CO}_{2}$ treatment at $0{ }^{\circ} \mathrm{C}$, applied in the skin, pulp, seeds 
and rachis of Cardinal table grapes. This was the first time that this scenario was described in relation to a gaseous treatment in plants. The outcomes have been recently confirmed in another table grape cultivar, Autumn Royal. In this case, Vazquez-Hernandez et al. [42] observed that unspliced forms showed a higher extent of regulation than spliced forms after the application of high levels of $\mathrm{CO}_{2}$ at $0{ }^{\circ} \mathrm{C}$. Although the functionality of unspliced DHNs is not well known, it has been observed that recombinant unspliced DHN1a variant of $V$. vinifera cv. Cardinal, slightly interacts with DNA. However, a potential role of spliced DHN forms has been indicated in protection against freezing and dehydration, as well as inhibiting $B$. cinerea growth [128].

Transcriptome sequencing using next-generation sequencing technologies has been increasingly carried out in model and non-model plants for gene detection and marker development. Compared with traditional laboratory methods, RNA-Seq is a high throughput technology, overcoming the weakness of microarrays in exploring unknown genes. To date, RNA-seq technology has been widely used to detect gene expression in different tissues such as berries, flowers and leaves, and in response to different environmental stresses [129-136]. Interestingly, although most grapevine transcriptome research has focused on wine grape cultivars due to their high economic demand, different studies have been performed over recent years in table grapes. Some of these examined global transcriptome changes during table grape ripening $[137,138]$ and in response to preharvest treatments $[139,140]$. Using RNA-seq and LC-MS/MS techniques, Zhang et al. [141] analyzed the resistance of Kyoho and Shine Muscat grapes to B. cinerea infection following chitosan treatment. They found that this treatment significantly regulated the emergence of fungal diseases, plant hormone biosynthesis, signal transduction and secondary metabolism. Moreover, an RNA-seq analysis revealed an enrichment of the genes involved in pyruvate metabolism and phenylpropanoid pathways in Superior Seedless table grapes stored at low-temperatures for 6 weeks under elevated $\mathrm{CO}_{2}$ levels [91].

The advent of genome editing now offers revolutionary tools to edit and completely knock out susceptibility genes in many crops, whilst preserving their cultivar and clonal genetic backgrounds. The CRISPR/Cas9 system has been utilized successfully for mutagenesis in a variety of organisms, including plants such as Arabidopsis, sorghum, rice, tomato, maize, wheat, potato, poplar, orange, liverwort, petunia, and cucumber (reviewed in [142]). In addition, it has been reported successful targeted mutagenesis in grape suspension cells or protoplast using the CRISPR/Cas9 system [143-145]. CRISPR/Cas9 technology was recently used to edit powdery mildew and downy mildew susceptibility genes, such as DOWNY MILDEW RESISTANCE 6 and Mildew Locus $O$, in different grapevine clones [146]. Moreover, CRISPR knockout of VvWRKY52 in grape increased resistance to B. cinerea [147]. Likewise, in a recent study, Li et al. [148] engineered loss-of-function mutations in the $V v P R 4 b$ gene from the cultivar Thompson Seedless using the CRISPR/Cas9 system. Results showed that VvPR4b knockout lines increased susceptibility to pathogen infection, which was accompanied by a reduced accumulation of ROS around stomata. These recent works confirm that grape is becoming a pioneering fruit crop in the area of transgene-free genome editing, however, further work is needed in order to modify table grapes and improve their quality during postharvest storage.

\section{Conclusions and Future Perspectives}

In the present day, different postharvest technologies are employed in order to improve table grape quality during postharvest storage. Consumer reluctance regarding the chemical treatment of agricultural products has promoted the use of physical treatments. These consist mainly of the control of the gaseous composition surrounding bunches during storage at temperatures around $0{ }^{\circ} \mathrm{C}$. For this reason, most currently existing published works analyze the mechanisms underlying the beneficial effects of postharvest treatments with regards to gaseous treatments. Such treatments exert effects to preserve grape firmness by maintaining the cell wall through the regulation of genes coding for cell wall degrading enzymes. Moreover, various postharvest treatments served to maintain membrane integrity, thus, water status seems to be an important factor to consider when analyzing different postharvest treatments. However, no common trends are seen in relation to the modulation of the antioxidant 
system through the application of postharvest treatments. Indeed, effects typically depend on the type of tissue analyzed. In contrast, most postharvest treatments served to control lipid peroxidation by reducing MDA content, with this being activated during cold storage. The phenylpropanoid pathway has been extensively studied due to its implications for the health-promoting properties of table grapes. These studies show that various treatments promote increased levels of the final compounds such as anthocyanins, stilbenes and flavanols, through the modulation of gene expression. However, some of these responses were cultivar-dependent. Evolution of molecular tools, such as microarrays and RNA-seq, has allowed to uncover the role of different transcription factors on the effectiveness of postharvest treatments applied to table grapes. These transcription factors were not only modulated at a transcriptional level by the different treatments, but there was also evidence of its role in the in vitro activation of target genes such as those coding for PRs and dehydrins (Figure 1).

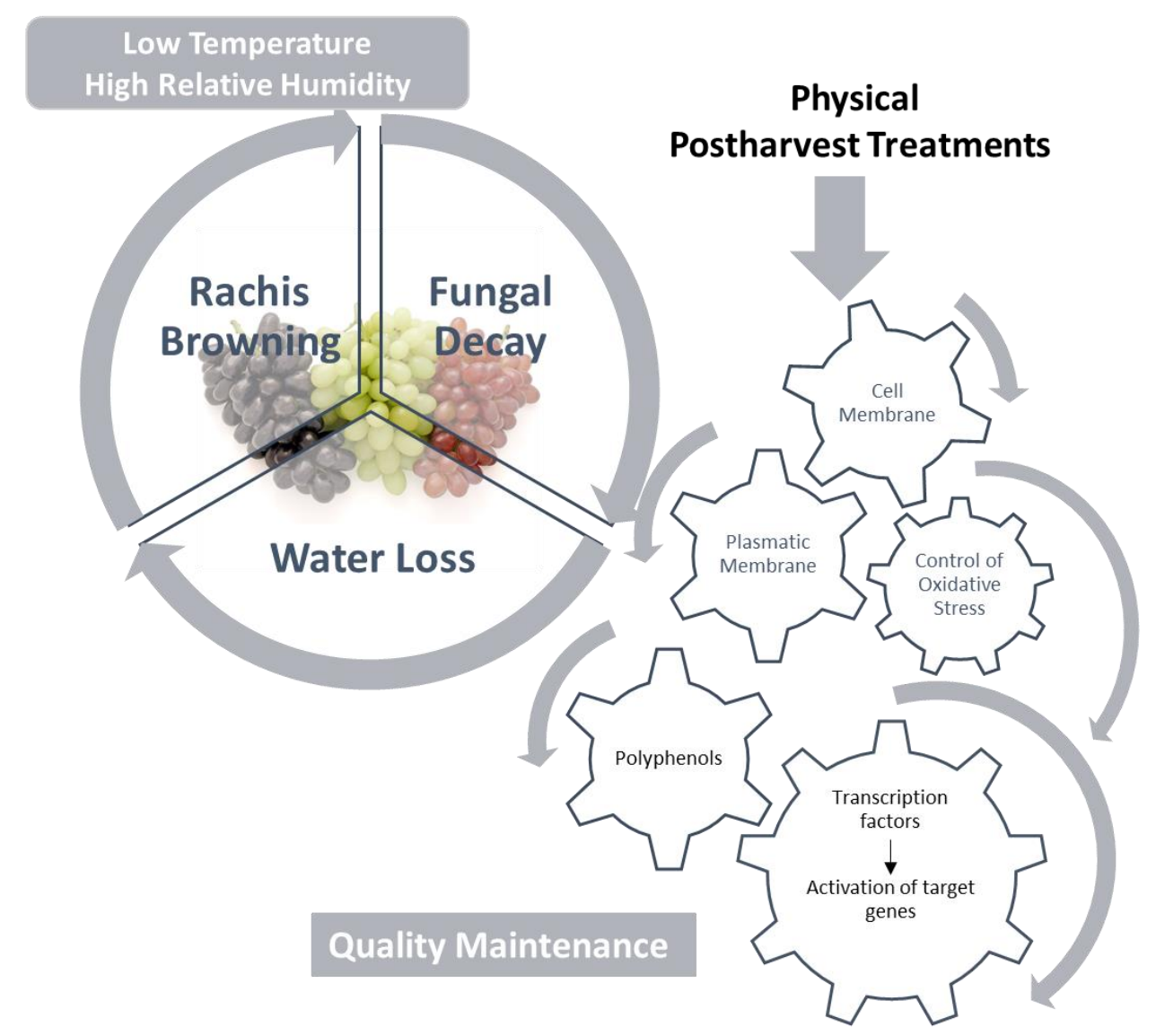

Figure 1. A scheme summarizing responses of table grapes to physical treatments during postharvest storage.

Finally, although most research using CRISPR/Cas9 gene-editing technology has been focused on improving susceptibility to pathogen infection in grapes, application of this system opens up an interesting research area to achieve better quality modified table grapes. Deepening knowledge around the molecular basis implicated in the maintenance of table grape quality should be a goal of future table grape postharvest research.

Author Contributions: M.T.S.-B. and I.R. conceived and designed the review manuscript; M.T.S.-B. wrote the review; I.R. revised the different manuscript drafts; I.M.-G. performed an exhaustive bibliographic search, M.V.-H., I.M.-G., M.I.E. and C.M. revised the manuscript. All authors have read and agreed to the published version of the manuscript.

Funding: This research was funded by the Spanish Ministerio de Economía y Competitividad and Fondo Europeo de Desarrollo Regional with the AGL2014-53081-R and AGL2017-85291-R (MINECO/AEI/FEDER, UE) projects.

Conflicts of Interest: The authors declare no conflict of interest. 


\section{Abbreviations}

$\begin{array}{ll}\text { ANR } & \text { Anthocyanidin reductase } \\ \text { AP2/ERF } & \text { APETALA2/ethylene response factor } \\ \text { APX } & \text { Ascorbate peroxidase } \\ \text { CAT } & \text { Catalase } \\ \text { CL } & \text { Cellulase } \\ \text { CHI } & \text { Chalcone isomerase } \\ \text { DFR } & \text { Dihydroflavonol 4-reductase } \\ \text { ERFs } & \text { Ethylene response factors } \\ \text { FLS } & \text { Flavanol synthase } \\ \text { F3H } & \text { Flavanone 3-hydroxylase } \\ \text { AOMT } & \text { Flavonoid } 3^{\prime}, 5^{\prime} \text {-methyltransferase } \\ \text { GR } & \text { Glutathione reductase } \\ \text { OIV } & \text { International Organization of Vine and Wine } \\ \text { LAR } & \text { Leucoanthocyanidin reductase } \\ \text { LDOX } & \text { Leucoanthocyanin dioxygenase } \\ \text { MDA } & \text { Malondialdehyde } \\ \text { PRs } & \text { Pathogenesis related proteins } \\ \text { PL } & \text { Pectate lyase } \\ \text { PE } & \text { Pectinesterase } \\ \text { POD } & \text { Peroxidase } \\ \text { PAL } & \text { Phenylalanine ammonia lyase } \\ \text { PG } & \text { Polygalacturonase } \\ \text { PPO } & \text { Polyphenol oxidase } \\ \text { ROS } & \text { Reactive oxygen species } \\ { }^{\circ} \text { Brix } & \text { Soluble, Solid content } \\ \text { STS } & \text { Stilbene synthase } \\ \text { SOD } & \text { Superoxide dismutase } \\ \text { SAR } & \text { Systemic acquired resistance } \\ \text { TIL } & \text { Temperature-induced lipocalin } \\ \text { UFGT } & \text { UDP-glucose: flavonoid 3-O-glucosyltransferase } \\ \text { XTH } & \text { Xyloglucan endotransglycosylase/hydrolase } \\ \beta-G A L & \text { } \text {-galactosidase } \\ & \end{array}$

\section{References}

1. Robinson, S.P.; Davies, C. Molecular biology of grape berry ripening. Aust. J. Grape Wine Res. 2000, 6, 175-188. [CrossRef]

2. Palou, L.; Serrano, M.; Martínez-Romero, D.; Valero, D. New approaches for postharvest quality retention of table grapes. Fresh Prod. 2010, 4, 103-110.

3. Romanazzi, G.; Lichter, A.; Gabler, F.M.; Smilanick, J.L. Recent advances on the use of natural and safe alternatives to conventional methods to control postharvest gray mold of table grapes. Postharvest Biol. Technol. 2012, 63, 141-147. [CrossRef]

4. Sonker, N.; Pandey, A.K.; Singh, P. Strategies to control post-harvest diseases of table grape: A review. J. Wine Res. 2016, 27, 105-122. [CrossRef]

5. De Simone, N.; Pace, B.; Grieco, F.; Chimienti, M.; Tyibilika, V.; Santoro, V.; Capozzi, V.; Colelli, G.; Spano, G.; Russo, P. Botrytis cinerea and Table Grapes: A Review of the Main Physical, Chemical, and Bio-Based Control Treatments in Post-Harvest. Foods 2020, 9, 1138. [CrossRef] [PubMed]

6. Albersheim, P.; Darvill, A.; Roberts, K.; Sederoff, R.; Staehelin, A. Plant Cell Walls from Chemistry to Biology, 1st ed.; Garland Science: New York, NY, USA, 2010; pp. 1-430.

7. Martínez-Lapuente, L.; Guadalupe, Z.; Ayestarán, B. Properties of Wine Polysaccharides. In Pectins-Extraction, Purification, Characterization and Applications; Masuelli, M., Ed.; IntechOpen: London, UK, 2019.

8. Cosgrove, D.J. Growth of the plant cell wall. Nat. Rev. Mol. Cell Biol. 2005, 6, 850-861. [CrossRef] 
9. Payasi, A.; Mishra, N.N.; Chaves, A.L.S.; Singh, R. Biochemistry of fruit softening: An overview. Physiol. Mol. Biol. Plants 2009, 15, 103-113. [CrossRef]

10. Nunan, K.J.; Sims, I.M.; Bacic, A.; Robinson, S.P.; Fincher, G.B. Changes in cell wall composition during ripening of grape berries. Plant Physiol. 1998, 118, 783-792. [CrossRef]

11. Ishimaru, M.; Kobayashi, S. Expression of a xyloglucan endo-transglycosylase gene is closely related to grape berry softening. Plant Sci. 2002, 162, 621-628. [CrossRef]

12. Correa, J.; Mamani, M.; Muñoz-Espinoza, C.; González-Agüero, M.; Defilippi, B.G.; Campos-Vargas, R.; Pinto, M.; Hinrichsen, P. New stable QTLs for berry firmness in table grapes. Am. J. Enol. Vitic. 2016, 67, 212-217. [CrossRef]

13. Wong, D.C.J.; Lopez Gutierrez, R.; Dimopoulos, N.; Gambetta, G.A.; Castellarin, S.D. Combined physiological, transcriptome, and cis-regulatory element analyses indicate that key aspects of ripening, metabolism, and transcriptional program in grapes (Vitis vinifera L.) are differentially modulated accordingly to fruit size. BMC Genomics 2016, 17, e416. [CrossRef] [PubMed]

14. Ma, L.; Sun, L.; Guo, Y.; Lin, H.; Liu, Z.; Li, K.; Guo, X. Transcriptome analysis of table grapes (Vitis vinifera L.) identified a gene network module associated with berry firmness. PLoS ONE 2020, 15, e0237526. [CrossRef] [PubMed]

15. Ejsmentewicz, T.; Balic, I.; Sanhueza, D.; Barria, R.; Meneses, C.; Orellana, A.; Prieto, H.; Defilippi, B.G.; Campos-Vargas, R. Comparative study of two table grape varieties with contrasting texture during cold storage. Molecules 2015, 20,3667-3680. [CrossRef] [PubMed]

16. Deng, Y.; Wu, Y.; Li, Y. Changes in firmness, cell wall composition and cell wall hydrolases of grapes stored in high oxygen atmospheres. Food Res. Int. 2005, 38, 769-776. [CrossRef]

17. Becatti, E.; Chkaiban, L.; Tonutti, P.; Forcato, C.; Bonghi, C.; Ranier, A.M. Short-term postharvest carbon dioxide treatments induce selective molecular and metabolic changes in grape berries. J. Agric. Food Chem. 2010, 58, 8012-8020. [CrossRef]

18. Bang, J.; Lim, S.; Yi, G.; Lee, J.G.; Lee, E.J. Integrated transcriptomic-metabolomic analysis reveals cellular responses of harvested strawberry fruit subjected to short-term exposure to high levels of carbon dioxide. Postharvest Biol. Technol. 2019, 148, 120-131. [CrossRef]

19. Besada, C.; Llorca, E.; Novillo, P.; Hernando, I.; Salvador, A. Short-term high $\mathrm{CO}_{2}$ treatment alleviates chilling injury of persimmon cv. Fuyu by preserving the parenchyma structure. Food Control. 2014, 51, 163-170. [CrossRef]

20. Blanch, M.; Fernandez-Caballero, C.; Sanchez-Ballesta, M.T.; Escribano, M.I.; Merodio, C. Accumulation and distribution of potassium and its association with water balance in the skin of Cardinal table grapes during storage. Sci. Hortic. 2014, 175, 223-228. [CrossRef]

21. Vazquez-Hernandez, M.; Blanch, M.; Sanchez-Ballesta, M.T.; Merodio, C.; Escribano, M.I. High $\mathrm{CO}_{2}$ alleviates cell ultrastructure damage in Autumn Royal table grapes by modulating fatty acid composition and membrane and cell oxidative status during long-term cold storage. Postharvest Biol. Technol. 2020, 160, 111037. [CrossRef]

22. Miura, K.; Furumoto, T. Cold signaling and cold response in plants. Int. J. Mol. Sci. 2013, 14, 5312-5337. [CrossRef]

23. Örvar, B.L.; Sangwan, V.; Omann, F.; Dhindsa, R.S. Early steps in cold sensing by plant cells: The role of actin cytoskeleton and membrane fluidity. Plant J. 2000, 23, 785-794. [CrossRef] [PubMed]

24. Beck, E.H.; Fettig, S.; Knake, C.; Hartig, K.; Bhattarai, T. Specific and unspecific responses of plants to cold and drought stress. J. Biosci. 2007, 32, 501-510. [CrossRef] [PubMed]

25. Deng, Y.; $\mathrm{Wu}, \mathrm{Y}$.; $\mathrm{Li}, \mathrm{Y}$. Effects of high $\mathrm{O}_{2}$ levels on post-harvest quality and shelf life of table grapes during long-term storage. Eur. Food Res. Technol. 2005, 221, 392-397. [CrossRef]

26. Rosales, R.; Romero, I.; Fernandez-Caballero, C.; Escribano, M.I.; Merodio, C.; Sanchez-Ballesta, M.T. Low temperature and short-term high- $\mathrm{CO}_{2}$ treatment in postharvest storage of table grapes at two maturity stages: Effects on transcriptome profiling. Front. Plant Sci. 2016, 7, e1020. [CrossRef] [PubMed]

27. Champa, H.A.H.; Gill, M.I.S.; Mahajan, B.V.C.; Arora, N.K. Postharvest treatment of polyamines maintains quality and extends shelf-life of table grapes (Vitis vinifera L.) cv. Flame Seedless. Postharvest Biol. Technol. 2014, 91, 57-63. [CrossRef] 
28. Blanch, M.; Alvarez, I.; Sanchez-Ballesta, M.T.; Escribano, M.I.; Merodio, C. Involvement of fatty acids in the response to high $\mathrm{CO}_{2}$ and low temperature in harvested strawberries. Postharvest Biol. Technol. 2019, 147, 196-205. [CrossRef]

29. Liang, S.; Kuang, J.; Ji, S.; Chen, Q.; Deng, W.; Min, T.; Shan, W.; Chen, J.; Lu, W. The membrane lipid metabolism in horticultural products suffering chilling injury. Food Qual. Saf. 2020, 4, 9-14. [CrossRef]

30. Wan, S.B.; Wang, W.; Wen, P.F.; Chen, J.Y.; Kong, W.F.; Pan, Q.H.; Zhan, J.C.; Tian, L.; Liu, H.T.; Huang, W.D. Cloning of phospholipase D from grape berry and its expression under heat acclimation. J. Biochem. Mol. Biol. 2007, 40, 595-603. [CrossRef]

31. Frenette Charron, J.B.; Breton, G.; Badawi, M.; Sarhan, F. Molecular and structural analyses of a novel temperature stress-induced lipocalin from wheat and Arabidopsis. FEBS Lett. 2002, 517, 129-132. [CrossRef]

32. Yun, Z.; Jin, S.; Ding, Y.; Wang, Z.; Gao, H.; Pan, Z.; Xu, J.; Cheng, Y.; Deng, X. Comparative transcriptomics and proteomics analysis of citrus fruit, to improve understanding of the effect of low temperature on maintaining fruit quality during lengthy post-harvest storage. J. Exp. Bot. 2012, 63, 2873-2893. [CrossRef]

33. Finkina, E.I.; Melnikova, D.N.; Bogdanov, I.V.; Ovchinnikova, T.V. Lipid transfer proteins as components of the plant innate immune system: Structure, functions, and applications. Acta Nat. 2016, 8, 47-61. [CrossRef]

34. Liu, F.; Zhang, X.; Lu, C.; Zeng, X.; Li, Y.; Fu, D.; Wu, G. Non-specific lipid transfer proteins in plants: Presenting new advances and an integrated functional analysis. J. Exp. Bot. 2015, 66, 5663-5681. [CrossRef] [PubMed]

35. Riederer, M.; Schreiber, L. Protecting against water loss: Analysis of the barrier properties of plant cuticles. J. Exp. Bot. 2001, 52, 2023-2032. [CrossRef] [PubMed]

36. Goñi, O.; Fernandez-Caballero, C.; Sanchez-Ballesta, M.T.; Escribano, M.I.; Merodio, C. Water status and quality improvement in high- $\mathrm{CO}_{2}$ treated table grapes. Food Chem. 2011, 128, 34-39. [CrossRef]

37. Blanch, M.; Sanchez-Ballesta, M.T.; Escribano, M.I.; Merodio, C. Water distribution and ionic balance in response to high $\mathrm{CO}_{2}$ treatments in strawberries (Fragaria vesca L. cv. Mara de Bois). Postharvest Biol. Technol. 2012, 73, 63-71. [CrossRef]

38. Tucker, G.A. Introduction BT-Biochemistry of Fruit Ripening; Seymour, G.B., Taylor, J.E., Tucker, G.A., Eds.; Springer: Dordrecht, The Netherlands, 1993; pp. 1-51.

39. Crisosto, C.H.; Smilanick, J.L.; Dokoozlian, N.K.; Luvisi, D.A. Maintaining table grape post-harvest quality for long distant markets. In Proceedings of the International Symposium on Table Grape Production, Anaheim, California, 28-29 June 1994; Rantz, J.M., Ed.; pp. 195-199.

40. Sanchez-Ballesta, M.T.; Jiménez, J.B.; Romero, I.; Orea, J.M.; Maldonado, R.; Ureña, Á.G.; Escribano, M.I.; Merodio, $\mathrm{C}$. Effect of high $\mathrm{CO}_{2}$ pretreatment on quality, fungal decay and molecular regulation of stilbene phytoalexin biosynthesis in stored table grapes. Postharvest Biol. Technol. 2006, 42, 209-216. [CrossRef]

41. Rosales, R.; Fernandez-Caballero, C.; Romero, I.; Escribano, M.I.; Merodio, C.; Sanchez-Ballesta, M.T. Molecular analysis of the improvement in rachis quality by high $\mathrm{CO}_{2}$ levels in table grapes stored at low temperature. Postharvest Biol. Technol. 2013, 77, 50-58. [CrossRef]

42. Vazquez-Hernandez, M.; Romero, I.; Escribano, M.I.; Merodio, C.; Sanchez-Ballesta, M.T. Deciphering the role of $\mathrm{CBF} / \mathrm{DREB}$ transcription factors and dehydrins in maintaining the quality of table grapes cv. Autumn Royal treated with high $\mathrm{CO}_{2}$ levels and stored at $0{ }^{\circ} \mathrm{C}$. Front. Plant Sci. 2017, 8, e1591. [CrossRef]

43. Artés-Hernández, F.; Aguayo, E.; Artés, F. Alternative atmosphere treatments for keeping quality of "Autumn seedless" table grapes during long-term cold storage. Postharvest Biol. Technol. 2004, 31, 59-67. [CrossRef]

44. Romero, I.; Domínguez, I.; Doménech-Carbó, A.; Gavara, R.; Escribano, M.I.; Merodio, C.; Sanchez-Ballesta, M.T. Effect of high levels of $\mathrm{CO}_{2}$ on the electrochemical behavior and the enzymatic and non-enzymatic antioxidant systems in black and white table grapes stored at $0{ }^{\circ}$ C. J. Sci. Food Agric. 2019, 99, 6859-6867. [CrossRef]

45. Bendel, P.; Zemah, H.; Kamenetsky, R.; Vergeldt, F.; Van As, H. Magnetization transfer and double-quantum filtered imaging as probes for motional restricted water in tulip bulbs. Magn. Reson. Imaging 2001, 19, 857-865. [CrossRef]

46. Vertucci, C.W.; Stushnoff, C. The state of water in acclimating vegetative buds from Malus and Amelanchier and its relationship to winter hardiness. Physiol. Plant. 1992, 86, 503-511. [CrossRef]

47. Wolfe, J.; Bryant, G.; Koster, K.L. What is "unfreezable water", how unfreezable is it and how much is there? Cryo Lett. 2002, 23, 157-166. 
48. Sevillano, L.; Sanchez-Ballesta, M.T.; Romojaro, F.; Flores, F.B. Physiological, hormonal and molecular mechanisms regulating chilling injury in horticultural species. Postharvest technologies applied to reduce its impact. J. Sci. Food Agric. 2009, 89, 555-573. [CrossRef]

49. Mittler, R. Oxidative stress, antioxidants and stress tolerance. Trends Plant Sci. 2002, 7, 405-410. [CrossRef]

50. Blokhina, O.; Virolainen, E.; Fagerstedt, K.V. Antioxidants, oxidative damage and oxygen deprivation stress: A review. Ann. Bot. 2003, 91, 179-194. [CrossRef]

51. Jaspers, P.; Kangasjärvi, J. Reactive oxygen species in abiotic stress signaling. Physiol. Plant. 2010, 138, 405-413. [CrossRef]

52. Baek, K.-H.; Skinner, D.Z. Production of reactive oxygen species by freezing stress and the protective roles of antioxidant enzymes in plants. J. Agric. Chem. Environ. 2012, 01,34-40. [CrossRef]

53. Pavez, L.; Hödar, C.; Olivares, F.; González, M.; Cambiazo, V. Effects of postharvest treatments on gene expression in Prunus persica fruit: Normal and altered ripening. Postharvest Biol. Technol. 2013, 75, 125-134. [CrossRef]

54. Martins, M.Q.; Rodrigues, W.P.; Fortunato, A.S.; Leitão, A.E.; Rodrigues, A.P.; Pais, I.P.; Martins, L.D.; Silva, M.J.; Reboredo, F.H.; Partelli, F.L.; et al. Protective response mechanisms to heat stress in interaction with high $\left[\mathrm{CO}_{2}\right]$ conditions in coffea spp. Front. Plant Sci. 2016, 7, e947. [CrossRef]

55. Blanch, M.; Rosales, R.; Goya, L.; Sanchez-Ballesta, M.T.; Escribano, M.I.; Merodio, C. NADP-malic enzyme and glutathione reductase contribute to glutathione regeneration in Fragaria vesca fruit treated with protective high $\mathrm{CO}_{2}$ concentrations. Postharvest Biol. Technol. 2013, 86, 431-436. [CrossRef]

56. Yuan, X.; Wu, Z.; Li, H.; Wang, Y.; Liu, F.; Cai, H.; Newlove, A.A.; Wang, Y. Biochemical and proteomic analysis of "Kyoho" grape (Vitis labruscana) berries during cold storage. Postharvest Biol. Technol. 2014, 88, 79-87. [CrossRef]

57. Ni, Z.J.; Hu, K.D.; Song, C.B.; Ma, R.H.; Li, Z.R.; Zheng, J.L.; Fu, L.H.; Wei, Z.J.; Zhang, H. Hydrogen sulfide alleviates postharvest senescence of grape by modulating the antioxidant defenses. Oxid. Med. Cell. Longev. 2016, 2016, 1-14. [CrossRef] [PubMed]

58. Giraud, E.; Ivanova, A.; Gordon, C.S.; Whelan, J.; Considine, M.J. Sulphur dioxide evokes a large scale reprogramming of the grape berry transcriptome associated with oxidative signalling and biotic defence responses. Plant Cell Environ. 2012, 35, 405-417. [CrossRef] [PubMed]

59. Morales, M.; Munné-Bosch, S. Malondialdehyde: Facts and Artifacts. Plant Physiol. 2019, 180, 1246-1250. [CrossRef] [PubMed]

60. Wang, Y.; Gao, L.; Wang, Q.; Zuo, J. Low temperature conditioning combined with methyl jasmonate can reduce chilling injury in bell pepper. Sci. Hortic. 2019, 243, 434-439. [CrossRef]

61. Habibi, F.; Ramezanian, A.; Rahemi, M.; Eshghi, S.; Guillén, F.; Serrano, M.; Valero, D. Postharvest treatments with $\gamma$-aminobutyric acid, methyl jasmonate, or methyl salicylate enhance chilling tolerance of blood orange fruit at prolonged cold storage. J. Sci. Food Agric. 2019, 99, 6408-6417. [CrossRef]

62. Li, Z.; Wang, L.; Xie, B.; Hu, S.; Zheng, Y.; Jin, P. Effects of exogenous calcium and calcium chelant on cold tolerance of postharvest loquat fruit. Sci. Hortic. 2020, 269, 109391. [CrossRef]

63. Zhang, Z.; Xu, J.; Chen, Y.; Wei, J.; Wu, B. Nitric oxide treatment maintains postharvest quality of table grapes by mitigation of oxidative damage. Postharvest Biol. Technol. 2019, 152, 9-18. [CrossRef]

64. Macheix, J.-J.; Fleuriet, A.; Billot, J. The main phenolics of fruits. In Fruit Phenolics, 1st ed.; Macheix, J.-J., Ed.; CRC Press: Boca Raton, FL, USA, 1990; pp. 1-116.

65. Šamec, D.; Piljac-Žegarac, J. Postharvest stability of antioxidant compounds in hawthorn and cornelian cherries at room and refrigerator temperatures-Comparison with blackberries, white and red grapes. Sci. Hortic. 2011, 131, 15-21. [CrossRef]

66. Meng, X.; Li, B.; Liu, J.; Tian, S. Physiological responses and quality attributes of table grape fruit to chitosan preharvest spray and postharvest coating during storage. Food Chem. 2008, 106, 501-508. [CrossRef]

67. Sheng, K.; Zheng, H.; Shui, S.; Yan, L.; Liu, C.; Zheng, L. Comparison of postharvest UV-B and UV-C treatments on table grape: Changes in phenolic compounds and their transcription of biosynthetic genes during storage. Postharvest Biol. Technol. 2018, 138, 74-81. [CrossRef]

68. Artés-Hernández, F.; Tomás-Barberán, F.A.; Artés, F. Modified atmosphere packaging preserves quality of $\mathrm{SO}_{2}$-free "Superior seedless" table grapes. Postharvest Biol. Technol. 2006, 39, 146-154. [CrossRef] 
69. Cantos, E.; Espín, J.C.; Tomás-Barberán, F.A. Postharvest induction modeling method using UV irradiation pulses for obtaining resveratrol-enriched table grapes: A new "Functional" fruit? J. Agric. Food Chem. 2001, 49, 5052-5058. [CrossRef] [PubMed]

70. Romero, I.; Fernandez Caballero, C.; Sanchez-Ballesta, M.T.; Escribano, M.I.; Merodio, C. Influence of the stage of ripeness on phenolic metabolism and antioxidant activity in table grapes exposed to different $\mathrm{CO}_{2}$ treatments. Postharvest Biol. Technol. 2009, 54, 118-121. [CrossRef]

71. Tinello, F.; Lante, A. Recent advances in controlling polyphenol oxidase activity of fruit and vegetable products. Innov. Food Sci. Emerg. Technol. 2018, 50, 73-83. [CrossRef]

72. Lichter, A.; Kaplunov, T.; Zutahy, Y.; Daus, A.; Alchanatis, V.; Ostrovsky, V.; Lurie, S. Physical and visual properties of grape rachis as affected by water vapor pressure deficit. Postharvest Biol. Technol. 2011, 59, 25-33. [CrossRef]

73. Carvajal-Millán, E.; Carvallo, T.; Orozco, J.A.; Martínez, M.A.; Tapia, I.; Guerrero, V.M.; Rascón-Chu, A.; Llamas, J.; Gardea, A.A. Polyphenol oxidase activity, color changes, and dehydration in table grape rachis during development and storage as affected by N-(2-chloro-4-pyridyl)-N-phenylurea. J. Agric. Food Chem. 2001, 49, 946-951. [CrossRef]

74. Kaur, S.; Arora, N.K.; Gill, K.B.S.; Sharma, S.; Gill, M.I.S. Hexanal formulation reduces rachis browning and postharvest losses in table grapes cv. 'Flame Seedless'. Sci. Hortic. 2019, 248, 265-273. [CrossRef]

75. Cheynier, V.; Comte, G.; Davies, K.M.; Lattanzio, V.; Martens, S. Plant phenolics: Recent advances on their biosynthesis, genetics, and ecophysiology. Plant Physiol. Biochem. 2013, 72, 1-20. [CrossRef]

76. Naikoo, M.I. Role and regulation of plants phenolics in abiotic stress tolerance: An overview. In Plant Signaling Molecules: Role and Regulation under Stressful Environments; Naikoo, M.I., Dar, M.I., Raghib, F., Jaleel, H., Ahmad, B., Raina, A., Khan, F.A., Eds.; Elsevier: Amsterdam, The Netherlands, 2019; pp. 157-168.

77. Sharma, A.; Shahzad, B.; Rehman, A.; Bhardwaj, R.; Landi, M.; Zheng, B. Response of phenylpropanoid pathway and the role of polyphenols in plants under abiotic stress. Molecules 2019, 24, 2452. [CrossRef] [PubMed]

78. Yadav, V.; Wang, Z.; Wei, C.; Amo, A.; Ahmed, B.; Yang, X.; Zhang, X. Phenylpropanoid pathway engineering: An emerging approach towards plant defense. Pathogens 2020, 9, 312. [CrossRef] [PubMed]

79. Dubrovina, A.S.; Kiselev, K. V Regulation of stilbene biosynthesis in plants. Planta 2017, 246, 597-623. [CrossRef]

80. Vannozzi, A.; Dry, I.B.; Fasoli, M.; Zenoni, S.; Lucchin, M. Genome-wide analysis of the grapevine stilbene synthase multigenic family: Genomic organization and expression profiles upon biotic and abiotic stresses. BMC Plant Biol. 2012, 12, e130. [CrossRef] [PubMed]

81. Zhu, Y.J.; Agbayani, R.; Jackson, M.C.; Tang, C.S.; Moore, P.H. Expression of the grapevine stilbene synthase gene VST1 in papaya provides increased resistance against diseases caused by Phytophthora palmivora. Planta 2004, 220, 241-250. [CrossRef] [PubMed]

82. Schwekendiek, A.; Spring, O.; Heyerick, A.; Pickel, B.; Pitsch, N.T.; Peschke, F.; de Keukeleire, D.; Weber, G. Constitutive expression of a grapevine stilbene synthase gene in transgenic hop (Humulus lupulus L.) yields resveratrol and its derivatives in substantial quantities. J. Agric. Food Chem. 2007, 55, 7002-7009. [CrossRef]

83. Huang, L.; Zhang, S.; Singer, S.D.; Yin, X.; Yang, J.; Wang, Y.; Wang, X. Expression of the grape VqSTS21 gene in Arabidopsis confers resistance to osmotic stress and biotrophic pathogens but not Botrytis cinerea. Front. Plant Sci. 2016, 7, e1379. [CrossRef]

84. Kiselev, K.V.; Aleynova, O.A. Influence of overexpression of stilbene synthase VaSTS7 gene on resveratrol production in transgenic cell cultures of grape Vitis amurensis Rupr. Appl. Biochem. Microbiol. 2016, 52, 56-60. [CrossRef]

85. Carlos-Hilario, L.; Shimshock, R.; Ng, C.; Bingham, J.-P.; Christopher, D.A. Screening Carica papaya native promoters driving stilbene synthase expression in Arabidopsis thaliana for resveratrol glucoside (piceid) synthesis. Plant Biotechnol. Rep. 2015, 9, 307-317. [CrossRef]

86. Cantos, E.; Espín, J.C.; Tomás-Barberán, F.A. Postharvest stilbene-enrichment of red and white table grape varieties using UV-C irradiation pulses. J. Agric. Food Chem. 2002, 50, 6322-6329. [CrossRef]

87. Freitas, P.M.; López-Gálvez, F.; Tudela, J.A.; Gil, M.I.; Allende, A. Postharvest treatment of table grapes with ultraviolet-C and chitosan coating preserves quality and increases stilbene content. Postharvest Biol. Technol. 2015, 105, 51-57. [CrossRef] 
88. Palou, L.; Crisosto, C.H.; Smilanick, J.L.; Adaskaveg, J.E.; Zoffoli, J.P. Effects of continuous 0.3 ppm ozone exposure on decay development and physiological responses of peaches and table grapes in cold storage. Postharvest Biol. Technol. 2002, 24, 39-48. [CrossRef]

89. Ahn, S.Y.; Kim, S.A.; Choi, S.J.; Yun, H.K. Comparison of accumulation of stilbene compounds and stilbene related gene expression in two grape berries irradiated with different light sources. Hortic. Environ. Biotechnol. 2015, 56, 36-43. [CrossRef]

90. Hasan, M.M.; Baek, K.-H. Induction of resveratrol biosynthesis in grape skins and leaves by ultrasonication treatment. Korean J. Hortic. Sci. Technol. 2013, 31, 496-502. [CrossRef]

91. Maoz, I.; De Rosso, M.; Kaplunov, T.; Vedova, A.D.; Sela, N.; Flamini, R.; Lewinsohn, E.; Lichter, A. Metabolomic and transcriptomic changes underlying cold and anaerobic stresses after storage of table grapes. Sci. Rep. 2019, 9, 1-14. [CrossRef] [PubMed]

92. Sanchez-Ballesta, M.T.; Alvarez, I.; Escribano, M.I.; Merodio, C.; Romero, I. Effect of high $\mathrm{CO}_{2}$ levels and low temperature on stilbene biosynthesis pathway gene expression and stilbenes production in white, red and black table grape cultivars during postharvest storage. Plant Physiol. Biochem. 2020, 151, 334-341. [CrossRef] [PubMed]

93. Hartmann, T. From waste products to ecochemicals: Fifty years research of plant secondary metabolism. Phytochemistry 2007, 68, 2831-2846. [CrossRef]

94. Amarowicz, R.; Carle, R.; Dongowski, G.; Durazzo, A.; Galensa, R.; Kammerer, D.; Maiani, G.; Piskula, M.K. Influence of postharvest processing and storage on the content of phenolic acids and flavonoids in foods. Mol. Nutr. Food Res. 2009, 53, S151-S183. [CrossRef]

95. Crupi, P.; Pichierri, A.; Basile, T.; Antonacci, D. Postharvest stilbenes and flavonoids enrichment of table grape cv Redglobe (Vitis vinifera L.) as affected by interactive UV-C exposure and storage conditions. Food Chem. 2013, 141, 802-808. [CrossRef]

96. Romero, I.; Domínguez, I.; Morales-Diaz, N.; Escribano, M.I.; Merodio, C.; Sanchez-Ballesta, M.T. Regulation of flavonoid biosynthesis pathway by a single or dual short-term $\mathrm{CO}_{2}$ treatment in black table grapes stored at low temperature. Plant Physiol. Biochem. 2020, 156, 30-38. [CrossRef]

97. Sanchez-Ballesta, M.T.; Romero, I.; Jiménez, J.B.; Orea, J.M.; González-Ureña, Á.; Escribano, M.I.; Merodio, C. Involvement of the phenylpropanoid pathway in the response of table grapes to low temperature and high $\mathrm{CO}_{2}$ levels. Postharvest Biol. Technol. 2007, 46, 29-35. [CrossRef]

98. Zhang, C.; Jia, H.; Wu, W.; Wang, X.; Fang, J.; Wang, C. Functional conservation analysis and expression modes of grape anthocyanin synthesis genes responsive to low temperature stress. Gene 2015, 574, 168-177. [CrossRef] [PubMed]

99. Yang, M.; Wang, L.; Belwal, T.; Zhang, X.; Lu, H.; Chen, C.; Li, L. Exogenous melatonin and abscisic acid expedite the flavonoids biosynthesis in grape berry of Vitis vinifera cv. Kyoho. Molecules 2020, $25,12$. [CrossRef] [PubMed]

100. De Pascual-Teresa, S.; Sanchez-Ballesta, M.T. Anthocyanins: From plant to health. Phytochem. Rev. 2008, 7, 281-299. [CrossRef]

101. Azuma, A.; Yakushiji, H.; Sato, A. Postharvest light irradiation and appropriate temperature treatment increase anthocyanin accumulation in grape berry skin. Postharvest Biol. Technol. 2019, 147, 89-99. [CrossRef]

102. Mori, K.; Sugaya, S.; Gemma, H. Decreased anthocyanin biosynthesis in grape berries grown under elevated night temperature condition. Sci. Hortic. 2005, 105, 319-330. [CrossRef]

103. Jaillon, O.; Aury, J.-M.; Noel, B.; Policriti, A.; Clepet, C.; Casagrande, A.; Choisne, N.; Aubourg, S.; Vitulo, N.; Jubin, C.; et al. The grapevine genome sequence suggests ancestral hexaploidization in major angiosperm phyla. Nature 2007, 449, 463-467. [CrossRef]

104. Velasco, R.; Zharkikh, A.; Troggio, M.; Cartwright, D.A.; Cestaro, A.; Pruss, D.; Pindo, M.; FitzGerald, L.M.; Vezzulli, S.; Reid, J.; et al. A high quality draft consensus sequence of the genome of a heterozygous grapevine variety. PLoS ONE 2007, 2, e1326. [CrossRef]

105. Canaguier, A.; Grimplet, J.; Di Gaspero, G.; Scalabrin, S.; Duchêne, E.; Choisne, N.; Mohellibi, N.; Guichard, C.; Rombauts, S.; Le Clainche, I.; et al. A new version of the grapevine reference genome assembly (12X.v2) and of its annotation (VCost.v3). Genom. Data 2017, 14, 56-62. [CrossRef]

106. Lijavetzky, D.; Carbonell-Bejerano, P.; Grimplet, J.; Bravo, G.; Flores, P.; Fenoll, J.; Hellín, P.; Oliveros, J.C.; Martínez-Zapater, J.M. Berry flesh and skin ripening features in Vitis vinifera as assessed by transcriptional profiling. PLoS ONE 2012, 7, e39547. [CrossRef] 
107. Xiao, H.; Siddiqua, M.; Braybrook, S.; Nassuth, A. Three grape CBF/DREB1 genes respond to low temperature, drought and abscisic acid. Plant Cell Environ. 2006, 29, 1410-1421. [CrossRef] [PubMed]

108. Wang, L.; Zhu, W.; Fang, L.; Sun, X.; Su, L.; Liang, Z.; Wang, N.; Londo, J.P.; Li, S.; Xin, H. Genome-wide identification of WRKY family genes and their response to cold stress in Vitis vinifera. BMC Plant Biol. 2014, 14, e103. [CrossRef] [PubMed]

109. Licausi, F.; Giorgi, F.M.; Zenoni, S.; Osti, F.; Pezzotti, M.; Perata, P. Genomic and transcriptomic analysis of the AP2/ERF superfamily in Vitis vinifera. BMC Genomics 2010, 11, e719. [CrossRef] [PubMed]

110. Londo, J.P.; Kovaleski, A.P.; Lillis, J.A. Divergence in the transcriptional landscape between low temperature and freeze shock in cultivated grapevine (Vitis vinifera). Hortic. Res. 2018, 5, e10. [CrossRef]

111. Zhu, D.; Hou, L.; Xiao, P.; Guo, Y.; Deyholos, M.K.; Liu, X. VvWRKY30, a grape WRKY transcription factor, plays a positive regulatory role under salinity stress. Plant Sci. 2019, 280, 132-142. [CrossRef]

112. Dimopoulos, N.; Tindjau, R.; Wong, D.C.J.; Matzat, T.; Haslam, T.; Song, C.; Gambetta, G.A.; Kunst, L.; Castellarin, S.D. Drought stress modulates cuticular wax composition of the grape berry. J. Exp. Bot. 2020, 71, 3126-3141. [CrossRef]

113. Romero, I.; Vazquez-Hernandez, M.; Escribano, M.I.; Merodio, C.; Sanchez-Ballesta, M.T. Expression profiles and DNA-binding affinity of five ERF genes in bunches of Vitis vinifera cv. Cardinal treated with high levels of $\mathrm{CO}_{2}$ at low temperature. Front. Plant Sci. 2016, 7, e1748. [CrossRef]

114. Romero, I.; Alegria-Carrasco, E.; Gonzalez de Pradena, A.; Vazquez-Hernandez, M.; Escribano, M.I.; Merodio, C.; Sanchez-Ballesta, M.T. WRKY transcription factors in the response of table grapes (cv. Autumn Royal) to high $\mathrm{CO}_{2}$ levels and low temperature. Postharvest Biol. Technol. 2019, 150, 42-51. [CrossRef]

115. Yin, X.; Allan, A.C.; Xu, Q.; Burdon, J.; Dejnoprat, S.; Chen, K.; Ferguson, I.B. Differential expression of kiwifruit ERF genes in response to postharvest abiotic stress. Postharvest Biol. Technol. 2012, 66, 1-7. [CrossRef]

116. Li, X.; Zhu, X.; Mao, J.; Zou, Y.; Fu, D.; Chen, W.; Lu, W. Isolation and characterization of ethylene response factor family genes during development, ethylene regulation and stress treatments in papaya fruit. Plant Physiol. Biochem. 2013, 70, 81-92. [CrossRef]

117. Busam, G.; Kassemeyer, H.H.; Matern, U. Differential expression of chitinases in Vitis vinifera L. responding to systemic acquired resistance activators or fungal challenge. Plant Physiol. 1997, 115, 1029-1038. [CrossRef] [PubMed]

118. Robinson, S.P.; Jacobs, A.K.; Dry, I.B. A class IV chitinase is highly expressed in grape berries during ripening. Plant Physiol. 1997, 114, 771-778. [CrossRef] [PubMed]

119. Enoki, S.; Suzuki, S. Pathogenesis-Related Proteins in Grape. In Grape and wine Biotechnology, 1st ed.; Morata, A., Loira, I., Eds.; IntechOpen: Rijeka, Croatia, 2016; pp. 43-59.

120. Nookaraju, A.; Agrawal, D.C. Enhanced tolerance of transgenic grapevines expressing chitinase and $\beta$-1,3-glucanase genes to downy mildew. Plant Cell Tissue Organ. Cult. 2012, 111, 15-28. [CrossRef]

121. Dhekney, S.A.; Li, Z.T.; Gray, D.J. Grapevines engineered to express cisgenic Vitis vinifera thaumatin-like protein exhibit fungal disease resistance. In Vitro Cell Dev. Biol. Plant 2011, 47, 458-466. [CrossRef]

122. Duarte-Sierra, A.; Aispuro-Hernández, E.; Vargas-Arispuro, I.; Islas-Osuna, M.A.; González-Aguilar, G.A.; Martínez-Téllez, M.Á. Quality and PR gene expression of table grapes treated with ozone and sulfur dioxide to control fungal decay. J. Sci. Food Agric. 2016, 96, 2018-2024. [CrossRef]

123. Wang, K.; Wu, D.; Bo, Z.; Chen, S.; Wang, Z.; Zheng, Y.; Fang, Y. Regulation of redox status contributes to priming defense against Botrytis cinerea in grape berries treated with $\beta$-aminobutyric acid. Sci. Hortic. 2019, 244, 352-364. [CrossRef]

124. Xiao, H.; Nassuth, A. Stress- and development-induced expression of spliced and unspliced transcripts from two highly similar dehydrin 1 genes in V. riparia and V. vinifera. Plant Cell Rep. 2006, 25, 968-977. [CrossRef]

125. Fernandez-Caballero, C.; Rosales, R.; Romero, I.; Escribano, M.I.; Merodio, C.; Sanchez-Ballesta, M.T. Unraveling the roles of $C B F 1, C B F 4$ and dehydrin 1 genes in the response of table grapes to high $\mathrm{CO}_{2}$ levels and low temperature. J. Plant Physiol. 2012, 169, 744-748. [CrossRef]

126. Yang, Y.; He, M.; Zhu, Z.; Li, S.; Xu, Y.; Zhang, C.; Singer, S.D.; Wang, Y. Identification of the dehydrin gene family from grapevine species and analysis of their responsiveness to various forms of abiotic and biotic stress. BMC Plant Biol. 2012, 12, e140. [CrossRef] 
127. Navarro, S.; Vazquez-Hernandez, M.; Rosales, R.; Sanchez-Ballesta, M.T.; Merodio, C.; Escribano, M.I. Differential regulation of dehydrin expression and trehalose levels in Cardinal table grape skin by low temperature and high $\mathrm{CO}_{2}$. J. Plant Physiol. 2015, 179, 1-11. [CrossRef]

128. Rosales, R.; Romero, I.; Escribano, M.I.; Merodio, C.; Sanchez-Ballesta, M.T. The crucial role of $\Phi$ - And K-segments in the in vitro functionality of Vitis vinifera dehydrin DHN1a. Phytochemistry 2014, 108, 17-25. [CrossRef] [PubMed]

129. Zenoni, S.; Ferrarini, A.; Giacomelli, E.; Xumerle, L.; Fasoli, M.; Malerba, G.; Bellin, D.; Pezzotti, M.; Delledonne, M. Characterization of transcriptional complexity during berry development in Vitis vinifera using RNA-Seq. Plant Physiol. 2010, 152, 1787-1795. [CrossRef] [PubMed]

130. Sweetman, C.; Wong, D.C.; Ford, C.M.; Drew, D.P. Transcriptome analysis at four developmental stages of grape berry (Vitis vinifera cv. Shiraz) provides insights into regulated and coordinated gene expression. BMC Genomics 2012, 13, e691. [CrossRef] [PubMed]

131. Liu, G.-T.; Wang, J.-F.; Cramer, G.; Dai, Z.-W.; Duan, W.; Xu, H.-G.; Wu, B.-H.; Fan, P.-G.; Wang, L.-J.; Li, S.-H. Transcriptomic analysis of grape (Vitis vinifera L.) leaves during and after recovery from heat stress. BMC Plant Biol. 2012, 12, e174. [CrossRef]

132. Cheng, C.; Jiao, C.; Singer, S.D.; Gao, M.; Xu, X.; Zhou, Y.; Li, Z.; Fei, Z.; Wang, Y.; Wang, X. Gibberellin-induced changes in the transcriptome of grapevine (Vitis labrusca $\times$ V. vinifera) cv. Kyoho flowers. BMC Genom. 2015, 16, e128. [CrossRef]

133. Domingos, S.; Fino, J.; Paulo, O.S.; Oliveira, C.M.; Goulao, L.F. Molecular candidates for early-stage flower-to-fruit transition in stenospermocarpic table grape (Vitis vinifera L.) inflorescences ascribed by differential transcriptome and metabolome profiles. Plant Sci. 2016, 244, 40-56. [CrossRef]

134. Haider, M.S.; Zhang, C.; Kurjogi, M.M.; Pervaiz, T.; Zheng, T.; Zhang, C.; Lide, C.; Shangguan, L.; Fang, J. Insights into grapevine defense response against drought as revealed by biochemical, physiological and RNA-Seq analysis. Sci. Rep. 2017, 7, e13134. [CrossRef]

135. Upadhyay, A.; Gaonkar, T.; Upadhyay, A.K.; Jogaiah, S.; Shinde, M.P.; Kadoo, N.Y.; Gupta, V.S. Global transcriptome analysis of grapevine (Vitis vinifera L.) leaves under salt stress reveals differential response at early and late stages of stress in table grape cv. Thompson Seedless. Plant Physiol. Biochem. 2018, 129, 168-179. [CrossRef]

136. Savoi, S.; Herrera, J.C.; Forneck, A.; Griesser, M. Transcriptomics of the grape berry shrivel ripening disorder. Plant Mol. Biol. 2019, 100, 285-301. [CrossRef]

137. Balic, I.; Vizoso, P.; Nilo-Poyanco, R.; Sanhueza, D.; Olmedo, P.; Sepúlveda, P.; Arriagada, C.; Defilippi, B.G.; Meneses, C.; Campos-Vargas, R. Transcriptome analysis during ripening of table grape berry cv. Thompson Seedless. PLoS ONE 2018, 13, e0190087. [CrossRef]

138. Wei, L.; Cao, Y.; Cheng, J.; Xiang, J.; Shen, B.; Wu, J. Comparative transcriptome analyses of a table grape 'Summer Black' and its early-ripening mutant 'Tiangong Moyu' identify candidate genes potentially involved in berry development and ripening. J. Plant Interact. 2020, 15, 213-222. [CrossRef]

139. Xu, L.; Yue, Q.; Bian, F.; Sun, H.; Zhai, H.; Yao, Y. Melatonin enhances phenolics accumulation partially via ethylene signaling and resulted in high antioxidant capacity in grape berries. Front. Plant Sci. 2017, 8, e1426. [CrossRef] [PubMed]

140. Meneses, M.; García-Rojas, M.; Muñoz-Espinoza, C.; Carrasco-Valenzuela, T.; Defilippi, B.; González-Agüero, M.; Meneses, C.; Infante, R.; Hinrichsen, P. Transcriptomic study of pedicels from GA(3)-treated table grape genotypes with different susceptibility to berry drop reveals responses elicited in cell wall yield, primary growth and phenylpropanoids synthesis. BMC Plant Biol. 2020, 20, e66. [CrossRef] [PubMed]

141. Zhang, Z.; Zhao, P.; Zhang, P.; Su, L.; Jia, H.; Wei, X.; Fang, J.; Jia, H. Integrative transcriptomics and metabolomics data exploring the effect of chitosan on postharvest grape resistance to Botrytis cinerea. Postharvest Biol. Technol. 2020, 167, 111248. [CrossRef]

142. Bortesi, L.; Fischer, R. The CRISPR/Cas9 system for plant genome editing and beyond. Biotechnol. Adv. 2015, 33, 41-52. [CrossRef]

143. Ren, C.; Liu, X.; Zhang, Z.; Wang, Y.; Duan, W.; Li, S.; Liang, Z. CRISPR/Cas9-mediated efficient targeted mutagenesis in Chardonnay (Vitis vinifera L.). Sci. Rep. 2016, 6, 32289. [CrossRef] 
144. Malnoy, M.; Viola, R.; Jung, M.-H.; Koo, O.-J.; Kim, S.; Kim, J.-S.; Velasco, R.; Nagamangala Kanchiswamy, C. DNA-free fenetically edited grapevine and apple protoplast using CRISPR/Cas9 ribonucleoproteins. Front. Plant Sci. 2016, 7, 1904. [CrossRef]

145. Nakajima, I.; Ban, Y.; Azuma, A.; Onoue, N.; Moriguchi, T.; Yamamoto, T.; Toki, S.; Endo, M. CRISPR/Cas9-mediated targeted mutagenesis in grape. PLoS ONE 2017, 12, e0177966. [CrossRef]

146. Giacomelli, L.; Zeilmaker, T.; Malnoy, M.; Rouppe van der Voort, J.; Moser, C. Generation of mildew-resistant grapevine clones via genome editing. In Proceedings of the XII International Conference on Grapevine Breeding and Genetics, Bordeaux, France, 15-20 July 2019; Delrot, S., Ollat, N., Gallusci, P., Eds.; Acta Horticulturae: Leuven, Belgium, 2019; Volume 1248, pp. 195-200.

147. Wang, X.; Tu, M.; Wang, D.; Liu, J.; Li, Y.; Li, Z.; Wang, Y.; Wang, X. CRISPR/Cas9-mediated efficient targeted mutagenesis in grape in the first generation. Plant Biotechnol. J. 2018, 16, 844-855. [CrossRef]

148. Li, M.-Y.; Jiao, Y.-T.; Wang, Y.-T.; Zhang, N.; Wang, B.-B.; Liu, R.-Q.; Yin, X.; Xu, Y.; Liu, G.-T. CRISPR/Cas9-mediated VvPR4b editing decreases downy mildew resistance in grapevine (Vitis vinifera $\mathrm{L}$.). Hortic. Res. 2020, 7, e149. [CrossRef]

Publisher's Note: MDPI stays neutral with regard to jurisdictional claims in published maps and institutional affiliations.

(C) 2020 by the authors. Licensee MDPI, Basel, Switzerland. This article is an open access article distributed under the terms and conditions of the Creative Commons Attribution (CC BY) license (http://creativecommons.org/licenses/by/4.0/). 